\title{
CORRESPONDENCE
}

\section{Will foreign-aid pledges materialize?}

Much has been made of the funding to support clean-energy and climateadaptation initiatives in developing countries pledged by industrialized countries at the 2010 United Nations Climate Change Conference in Cancún, Mexico (Nature 468, $875-876 ; 2010)$. Yet if history is any guide, it is questionable whether these funds will materialize.

Nine years ago in Monterrey, Mexico, the same industrialized nations reaffirmed their commitment to allocate $0.7 \%$ of gross national income for official development assistance (ODA). This target was originally mandated by a 1970 UN general resolution that has never been honoured. The ODA peaked in 1982, when it reached just $0.36 \%$ of the combined gross national income of countries within the Organisation for Economic Cooperation and Development (OECD).

In 2009, that proportion was languishing at $0.31 \%$. This shortfall in annual funding amounted to US\$155 billion, which is substantially more than the Cancún pledge of $\$ 100$ billion by 2020 . If one assumes an average annual growth rate of $2 \%$ for OECD economies, by 2020 a further $\$ 68$ billion of the ODA will still be 'owed' to developing countries.

Even if the Cancún pledges are realized by 2020 , they will offset only half of the deficit in the long-promised ODA. Without a more generous and decisive attitude from industrialized countries and legally binding commitments backed up by sanctions, the Cancún pledge will do little to raise the hopes of the world's two billion poorest people.
Mike Hulme University of East Anglia, UK.

m.hulme@uea.ac.uk

\section{Innovation: venture capital is vital too}

Technology-transfer policies stemming from the Bayh-Dole Act (Nature 468, 755-756; 2010) may not always help emerging markets. They risk alienating the venture capitalists needed for commercializing early-stage innovation in places where governments control patents for taxpayer-funded research.

For example, export controls tethered to national technologytransfer policy can prevent venture capitalists from selling investments abroad, hindering the growth of a domestic industry. Ironically, underdeveloped local capital markets discourage capital flow for early-stage technology because of poor financial returns. This diminishes late-stage funding from banks and multinationals, thereby strangling the entire innovation system.

South Africa's nascent biotechnology industry has been a victim of such policies at the hands of the Technology Innovation Agency (TIA) the last remaining funder for commercialization. The TIA now has an annual budget of just US\$60 million or so to cover health, manufacturing, agriculture, mining, information technology and industrial biotech. BioVentures, the only life-sciences fund in subSaharan Africa, ranks in the top tenth of funds globally. It returns roughly three times the capital invested in it and is responsible for several successful domestic start-ups. But export controls meant that it was unable to raise a follow-up fund.

Venture capitalists also act as global intermediaries in collecting the best research and development technologies. Even with sufficient capital, government-run commercialization funders can crowd out private-sector investment and provide lesseffective mentoring. This is reflected in losses of around 60 cents per dollar of biotech investment by Canadian labour-sponsored funds - a major source of venture capital.

Successful innovation requires both government and venture-capital financing. Governments must be patient and strike the right balance between overall economic and domestic innovation. Justin Chakma University of Toronto, Canada. justin.chakma@utoronto.ca Stephen M. Sammut University of Pennsylvania and Burrill \& Company, USA.

\section{Cutting random funding decisions}

We find that for one-third of grant applications in 2009 to Australia's National Health and Medical Research Council, success is random owing to variability among peer reviewers. Increased competition for restricted research budgets means we must rectify this element of chance in selection.

A quota limiting the number of proposals per applicant would thwart researchers who have a high success rate, while improving the odds for others. Barring unsuccessful applicants for one 'cooling-off' round is another idea (Nature 464, 474-475; 2010).

Simplifying the application process would reduce costs for both applicants and peer reviewers (for example, some funding agencies request superfluous information). It would help in recruiting good peer reviewers and cut the likelihood of random decisions.

Funding for projects could be retrospective, as in some UK research institutions (D. F. Ball and J. Butler R\&D Mgmt 34, 87-97; 2004). Researchers would complete their research before applying, and then use the award for their next project.

Nicholas Graves, Adrian G.

Barnett Queensland University of Technology, Australia. n.graves@qut.edu.au Philip Clarke The University of Sydney, Australia.

\section{Bioethanol's dirty footprint in Brazil}

We believe that insufficient attention is paid to the social and environmental costs incurred at regional scales by biofuel production in Brazil (A. K. Duailibe Nature 468, 1041; 2010).

Brazil's Alagoas state covers almost 28,000 square kilometres, roughly half of which used to be rainforest. Sugar-cane plantations have now taken over coastal regions, including flood plains.

A study commissioned by the Alagoas government reveals that just $13.1 \%$ of the state's original rainforest has survived 35 years of the sugar-cane ethanol programme. This amounts to an average loss of 3,736 hectares of rainforest per year in what was formerly one of the world's 34 biodiversity hotspots. This environmental catastrophe is already taking its toll. Heavy rainfall in the region last year led to severe floods that destroyed thousands of buildings.

Despite academic and political controversy, most people believe biofuels to be 'clean'. In fact, ethanol production leaves a dirty footprint in one of Brazil's poorest states.

Lindemberg Medeiros de Araujo, Flávia de Barros Prado Moura Universidade Federal de Alagoas, Brazil. lindemberg@pq.cnpq.br 